\title{
Enhancing Border Security through Public-Private Partnerships in South Africa
}

\author{
Moses Thabo Katjisa Nkhoma ${ }^{a}$, Albert Tchey Agbenyegah ${ }^{b}$, ${ }^{a}$ Department of \\ Business Administration, Faculty of Management Sciences, Durban University \\ of Technology, South Africa. ${ }^{\text {b}}$ Durban University of Technology, Riverside \\ Campus, Pietermaritzburg South Africa, Faculty of Management Sciences, \\ Department of Applied Management. Email: a'mnkhoma@hotmail.co.za, \\ balberta@dut.ac.za
}

This study sought to explore the opportunities in forming effective partnerships between the public sector and the private space technology sector to address border security challenges in South Africa using space technology. The study focused on border security authorities and the space technology sector in South Africa. To achieve the above objective, a qualitative research methodology was used to ascertain the possibilities and opportunities of adopting Public-Private Partnerships (PPPs) to enhance border security in South Africa through the adoption of space technology. Findings indicate that there is a need for effective PPPs for the purpose of enhancing border security through the application of space technology in South Africa. The findings further highlighted the massive benefits of partnership but also highlighted the possible challenges of engaging in PPPs. This study revealed that it is reasonably expected for the South African border security authorities to collaborate with the private space technology sector for the purpose of developing and providing effective space technology for border security.

Key words: border security; space technology; public-private partnerships, satellite technology, unmanned aerial vehicle

\section{Introduction}

The private sector continues to be an important source of technological concepts and products. With South Africa continuing to be affected by various cross-border criminal activities due to the inability of border security authorities to effectively address the various threats and risks to border security, it has emerged that space-based technologies are being recognised by many 
developed countries as a solution for most of their border security challenges. It has also been recognised that the private space-technology sector continues to play a critical role in the provision of effective technological solutions for various national security programs Against this background, this study sought to explore the opportunities of forming partnerships between public sector institutions responsible for border security in South Africa, other government departments, the private space technology sector, and other private interests to address the country's land border security challenges through the application of space technologies.

\section{Statement of the problem}

There is lack of effective partnerships among public sector entities that are responsible for border security in South Africa and the private space technology sector for the purpose of enhancing land border security in the country. This is despite recognition in many developed countries of the value of effective partnerships in various national security programs. As described by Kawakubo (2017), the state is unable to efficiently emerge security challenges namely the growing levels of organised crime. Further study by Busch and Givens (2012) adds that the critical societal role of PPPs in homeland security matters particularly in enhancing resource utilisation, specialisation, and technological innovation cannot be left unnoticed. Clark, Cordes and Roberts (2006) also advance that the state role in homeland security could be enhanced through significant participation by both national and local governments, and the private sector.

Given the above, it can be argued that state institutions do not have the necessary resources and expertise to utilised space technology for enhancing border security in South Africa. Moreover, the task of securing the country's borders has become an extensive and daunting operations that cannot be accomplished alone by public sector establishments. Effective collaborations through the formation of suitable partnership between South Africa's border security authorities, other government departments, the private space technology industry, and other private entities has become an essential machinery in addressing the security challenges across the land borders of South Africa. Space technology according to recent studies significant role in monitoring and controlling national territories because it offers more flexibility and mobility (Motlagh, Bagaa \& Taleb, 2017). Similar study echoed the sentiments that space technology assist in managing other societal applications such as disaster management, communication, and traffic management (Gadda \& Patil, 2013; Motlagh, Bagaa \& Taleb, 2017; Liu, Liu, Shi, $\mathrm{Wu} \&$ Chen, 2019). The private space technology industry possesses requisite capability to provide enough technology, products and service solutions necessary for enhancing land border security. Thus, employing space technology through suitable and effective PPP models, could provide an operational advantage that would significantly enhance the efficiency and effectiveness of land border security in South Africa (Anderson, 2008). 


\section{Aim and objectives}

The study explored the opportunities partnerships between the public border security sector and the private space technology industry to enhance border security in South Africa. Therefore, the objective of this study is:

- To explore the extent to which the partnerships between border security authorities and the private space technology industry could be implemented to enhance land border security in South Africa; and

- To propose a partnership model in line with the envisaged partnership.

\section{Overview of Public-private partnerships}

\section{Definition and history of public-private partnerships}

There is no single definition of a PPP, which academics and practitioners could agree on (Levai, 2012; da Cruz \& Marques, 2013). However, authors such as Farlam (2005) defines a PPP as a contract between a public sector institution and a private party where the private party assumes substantial financial, technical, and operational risks of the project. Grimsey and Lewis (2002) further define a PPP as long-term contractual agreement between public sector and private sector bodies for the construction or management of public sector infrastructure facilities by the private sector entity, or the provision of services by the private sector entity on behalf of a public sector entity. A further definition is outlined by the Canadian Council for Public-Private Partnerships (CCPPP, 2009), where the term PPP is defined as a cooperative venture between the public and private sector, which is built upon the expertise of each partner that best meets clearly defined public needs through the appropriate allocation of resources, risk and rewards. In broad terms, Byiers, Große-Puppendahl, Huyse, Rosengren and Vaes (2016) define a PPP as a policy approach, which involves public support for private investments with the main aim of achieving certain public benefits alongside private profit based on the principle of shared risks and responsibilities.

PPPs have been a feature of service delivery in several countries in recent years and have emerged to be an important alternative to the conventional approaches of public service production and delivery, and the realisation of large infrastructural projects (Cuttaree, 2008; Webb \& Pulle, 2002; Nederhand \& Klijn, 2019). PPPs were originally used in the USA in the 1960s to give effect to urban development projects involving private investors. This resulted in the rapid recognition of PPPs throughout the world. In the 1990s, the United Kingdom (UK) incepted what was termed a Private Finance Initiative (PFI). PPPs continue to be globally recognised as an alternative method applied by the public sector for the procurement of services and goods, such as in the area of social and economic infrastructure management (Spackman, 
2002; Alfen, 2010; Fosler \& Berger, 1982). PPPs have been employed in many projects to procure public works and services globally. During the initial inception of PPPs, the focus was mainly on public infrastructure projects such as roads, prisons, railways, and power generation. However, PPPs have been expanded to provide social infrastructure, such as schools, health services, and hospitals (Colverson, 2011; Osbourne, 2000). Budget deficits, lack of expertise and innovation, and a need for greater efficiency in the public service have compelled several countries to adopt alternative methods of delivering a variety of public infrastructure and services such as transportation, schools, prisons, hospitals, and water treatment. Alternative methods of providing public infrastructure and services used by many countries consist of the total privatisation of state-owned enterprises; contracting out of certain public services; and/or using private finances to provide social infrastructure and services (Cuttaree, 2008; Dulaimi, Alhashemi, Ling \& Kumaraswamy, 2010). Against this background, partnerships between the public and private sectors are being acknowledged by many countries as an alternative to the traditional methods of providing public infrastructure and services solely through state entities (Kent, 1998; Webb \& Pulle, 2002).

\section{Public-private partnerships in the provision of national security services}

The provision of national security has typically been a function of states. This has been and continues to be more relevant in modern liberal capitalist societies where states have been tasked to carry out duties of providing security to their citizens and protecting their borders and critical interests. However, there has been a fundamental shift away from the liberal norm where the provision of security through private military and security contractors has gained popularity globally. To this end, the international arena is experiencing an increase in the number of private security and military companies rendering services in the international stage. Private security and military companies undertake a variety of activities that would have traditionally been performed by state security institutions. Such activities include security services; crime prevention services; military operational support; logistical support; and military advice (Avant, 2005; Kinsey, 2006; Gwatiwa, 2016; Abrahamsen \& Williams, 2011). With the private sector playing a significant role in the provision of safety and security in other countries, it is also acknowledged that the daunting task of securing any country's borders requires the involvement of the private sector (Carter, 2008; Busch \& Givens, 2012). Regrettably, there is a lack of recognition of the important role that the private sector could play in enhancing border security in South Africa. This is perhaps caused by a void between business and national security agencies when it comes to appreciating each other's capabilities and limitations, and the reluctance to deviate from traditional norms of providing border security exclusively through state security agencies (Gadda \& Patil, 2013; Motlagh, Bagaa \& Taleb, 2017; Liu, Liu, Shi, Wu \& Chen, 2019).

The current situation in the South African border environment renders it essential for the government to explore alternative means of providing effective border security. Thus, the employment of solid partnerships between the state and private sector could be of value in 
enhancing border security in South Africa, and as mentioned by Kawakubo (2017), the state on its own cannot manage emerging security challenges such as organised crime. In support, Busch and Given (2012) emphasise the growing role of PPPs in homeland security matters and further comment that PPPs can enhance issues such as resource utilisation, specialisation, and technological innovation. Similar sentiments are held by Clark et al. (2006) when they state that although it is acknowledged that the state plays a central role on issues of homeland security, the provision of greater homeland security could be enhanced through significant participation by national and local governments, and the private sector. PPPs have also been embraced as being the best approach to meet the challenges of other national security programmes, such as cyber security, by enabling greater cooperation between the private and public sectors to meet shared challenges (Dunn \& Cavelty, 2014; Carr, 2016; McCharty, 2018).

\section{Public-private partnerships in space technology projects}

The adoption of PPPs in space technology projects did not become relevant until the late 1990s, when the USA and Europe made efforts to build close partnerships between the public and private space sectors. However, the participation of the private sector was limited because of the huge risks associated with space projects. In the 1980s, Europe established a joint venture of national space agencies and space industries in what was termed the Arianespace. This resulted in the commercial launch of the European-made Ariane launch vehicle, where the responsibility of the private partner was limited to the operational phase of the project. During the same period, the US government also attempted to privatise the Landsat program, which was the US's land remote sensing satellite capability. However, this was reduced to the transfer of operations to a private party (Harvey, 2013). Since then, the space industry has continued to mirror other sectors of the economy by introducing PPPs in several space applications, such as remote sensing, global navigation, international communication systems, spaceports and space solar power systems. Through this approach, the expectation of various governments was that the expanded participation of the private sector would enhance the efficiencies of the space programmes and further foster the competitive domestic space industry (Howard, 2008).

Space-based PPPs have also entered strategic sectors, such as the military. This was initially seen in two PPP projects that were initiated in the UK and the European Union (EU), namely the Skynet 5 project, initiated in 2003, and the Galileo concession. The Skynet 5 project was conceived because of the need to develop a military communication system that would replace the Skynet 4 satellites. The UK government opted for a PPP, as it was believed that it would save the government $£ 500 \mathrm{~m}$ over the lifetime of the contract (Chuter, 2007; Betran \& Vidal, 2005; Iron \& Davidian, 2008). In the African context, advanced countries such as South Africa, Nigeria, Egypt, Morocco, and Algeria have the capability to undertake a variety of space projects. Each of these African countries has a national space agency and has some form of space policy to guide the implementation of their space projects. Egypt is a leading African 
country in the number of space projects, followed by South Africa (Dahir, 2018; Scatteia, Frayling \& Atie, 2020).

South Africa, like other developed countries, relies on several organisations including private companies, academic institutions, science councils, and study-based institutions, which can design and develop space technologies. These institutions include Sunspace, Cape Peninsula University of Technology, and the University of Stellenbosch. Thus, the infrastructure and skilled workforce from all these institutions and other institutions allows South Africa to better position itself as a hub of space science and technology on the African continent. Thus, as opposed to other African countries that buy satellites and then launch them, South Africa is capable of developing and manufacturing its own satellites, such as in the case of Sunsat, Sumbandila and Tshepiso, through effective collaboration with academic institutions and space companies (Parliamentary Monitoring Group, 2017; Wood \& Weigel, 2012; South Africa, 2020). Other projects in South Africa, which saw the collaboration of several actors across various industries, was the construction of the Karoo Array Telescope (MeerKAT), the predecessor for the Square Kilometre Array (SKA) in the Northern Cape Province. The development of the SKA, which is the largest radio telescope in the world, saw the involvement of a consortium of 100 organisations from 20 countries. It was reported that South Africa spent R1.2 billion to fund the SKA project, including MeerKAT. Another collaborator in space projects is Denel's Spaceteq, which is a subsidiary of Denel Dynamics, which is entirely owned by the South African government. Spaceteq can develop complete satellites, components, control systems and software. Leading private sector companies, such as the Cape SCS Aerospace Group, which is a corporation of four of South Africa's major space companies-NewSpace Systems, the Space Advisory Company, SCS Space and Space4Development-has provided space technology products and services to 19 countries on five continents (Ibeh, 2018; Spaceteq, 2020; Denner, 2018).

The private space technology sector in Africa in the field of remote sensing and geospatial technology has also increased its involvement in addressing Africa's policy, scientific and practical challenges during the past 20 years. About 50 percent of these companies are situated in countries like South Africa, Nigeria, Kenya, and Ethiopia. International private space technology companies are also collaborating or using the expertise of local companies to expand their market in Africa and to develop capacity-building facilities, which they can use together (Spacewatch Africa, 2018). According to Chumba, Okoth and Were (2016), the development of effective space technology for border security in Kenya and Somalia requires both governments to fund and support the development of the required security technologies in order to achieve the objectives of border surveillance and control. Thus, the development of superior border security technology would not only require funding, but also require collaborations in providing additional resources, and the most suitable means would be the involvement of the private sector. This approach would not only save resources for these two 
governments but would further allow the private sector to use its knowledge, skills, and creativity to develop border infrastructure that is also commerce friendly (Chumba et al., 2016).

Similar to the satellite technology industry, there are emerging collaborations between governments and private drone industries such as in the US, where the Federal Aviation Administration (FDA) has announced that it will collaborate with the private drone industry to support the drone safety integration network. The envisaged partnership would deliver several benefits, including the safe and efficient integration of drones, which in turn will provide the private drone industry with the opportunity to gain valuable experience related to drone technology. They will also ensure that collective efforts are undertaken to resolve difficult technical and operational challenges (Thompson-Hine, 2017; Corner Alliance, 2020). Washington (2018) emphasise that governments across the world should make efforts to partner with the private sector for developing drone technology. The author (2018) referred to organisations, such as Lockheed Martin, Northrup Grumman and Boeing, who are leaders in drone development for military purposes. Moreover, other smaller companies such as Parrot, Matternet, Zipline and GoPro are also developing and implementing drone solutions in many countries that leverage small drones to solve current societal problems. South Africa also has a strong private UAV industry and is a big producer of UAVs. This was acknowledged by the Minister of Defence who said that, considering the abundance of available and developing technologies, these technologies could be enhanced to meet at least $60 \%$ of South Africa's technology localisation for the purpose of realising its border security needs (DefenceWeb, 2017).

Major role players in the South African UAV industry are Denel and CSIR. Denel manufactured the Seeker 400, equipped with sophisticated systems, which could be used for aerial surveillance, while the CSIR developed Indiza, a small hand-launched drone equipped with various camera modules, a $3 \mathrm{G}$ mobile phone-based camera, and a towable high-definition wide-angle video camera, which could be used for border security missions (CSIR, 2019; Martin, 2019). Partnerships consisting of border security agencies, other government agencies, universities and researchers should be explored to focus on efforts to resolve security, humanitarian, environmental and wildlife challenges. Such partnerships will be of great value in helping to drive innovation in satellite and drone development and usage in each of the aforementioned areas. The employment of space technology through effective PPPs could provide an operational advantage that would significantly enhance the efficiency and effectiveness of border security and other in South Africa (Anderson, 2008).

\section{Methodology}

A qualitative approach consisting of document analysis and semi-structured interviews was used in this study. Document analysis consisted of the collection and analysis of official South African National Defence Force (SANDF) statements and reports. The researcher also conducted semi-structured interviews with members of SAPS border policing (36\%) and 
subjects' experts in border security (29\%), UAV specialists (29\%) and space technology (7\%). The data collected during this study was instrumental to the understanding of the phenomenon under study and in providing practical solutions to the identified problem.

\section{Data collection and analysis}

One of the data collection methods used by the researcher to explore the extent to which the partnerships between border security authorities and the private space technology industry could be implemented to enhance land border security in South Africa, was documentary analysis. The researcher, as guided by De Vos, Strydom, Fouche, and Delport (2005), studied and analysed official SANDF documents consisting of official statements and media reports. Other documents collected by the researcher were video and audio interview recordings of senior members of the SANDF. These documents were obtained mainly from the world-wideweb and the videos were sourced from various media houses such as the South African Broadcasting Authority (SABC) and eNCA through YouTube. In addition, the researcher collected data by applying Key Informant Interviews (KII) whilst using semi-structured interviews. A small number of participants with in-depth knowledge of the topic at hand were interviewed (Kumar, 1989; Given, 2008; Graton \& Jones, 2004). Participants in this study consisted of senior police officials responsible for land border security at selected land border areas in South Africa; researchers and experts on border security; researchers and experts on satellite technology; and researchers and experts on UAV technology. Due to practical constraints, and in consideration of the restrictions imposed by the Covid 19 pandemic and the related safety protocols, the researcher used virtual interview methods to collect data from the participants. Therefore, the researcher conducted video interviews, telephonic interviews, and email interviews with the identified.

The researcher used thematic analysis to analyse data collected in this research (Braun \& Clarke, 2006). To simplify the data analysis process, the audio recordings obtained during the semi-structured interviews were transcribed verbatim into notes so that they could be read, edited for accuracy, commented on, and analysed in order to identify common themes (Welman, Kruger, \& Mitchel, 2005). This was followed by the use of a Computer-Aided Qualitative Data Analysis Software (CAQDAS), Atlas ti ${ }^{\mathrm{TM}}$ to code the semi-structured interview transcripts (DeNardo \& Levers, 2002; Corti \& Gregory, 2011). The use of CAQDAS made it easy to analyse textual data and further made it easier to identify key themes as they emerged from the collected data.

\section{Findings}

The analysis of documentary sources revealed that South Africa has a strong private hi-tech industry, which is capable of innovating and developing technologies for defence and security. The analysis of documentary sources also indicated that South Africa has the capacity to produce security technologies such as drones (Kesteloo, 2019). It has also been recognised that 
the private sector could play a critical role in the development of the required technologies for border security in South Africa. In this instance, the Minister of Defence emphasised the need to co-opt the capabilities of the private sector and state-owned entities in order to provide technological solutions that would address the challenges of border security in South Africa (Department of Defence, 2017). In addition, almost all (86\%) of the participants in this study agreed that effective partnerships were necessary for the enhancement of border security through the utilisation of space technology in South Africa and only $14 \%$ of the participants were not in agreement of the envisaged partnerships. Considering this, the opinions of the participants as depicted in Figure 1 indicate that effective partnerships will result in a number of benefits in the border security environment such an enhanced border security system, the provision and sharing of skilled people, research development and innovation, and private sector financing each at a relative frequency of $16 \%$. Other benefits were SME and market development and economic benefits each at 13\%; innovation and sharing of expertise both at a relative frequency of $11 \%$. The participants also mentioned integration of technological systems at $8 \%$. The least mentioned benefit were ROI and efficiency at $5 \%$ each.

Figure 1: Opportunities of PPPs for border security

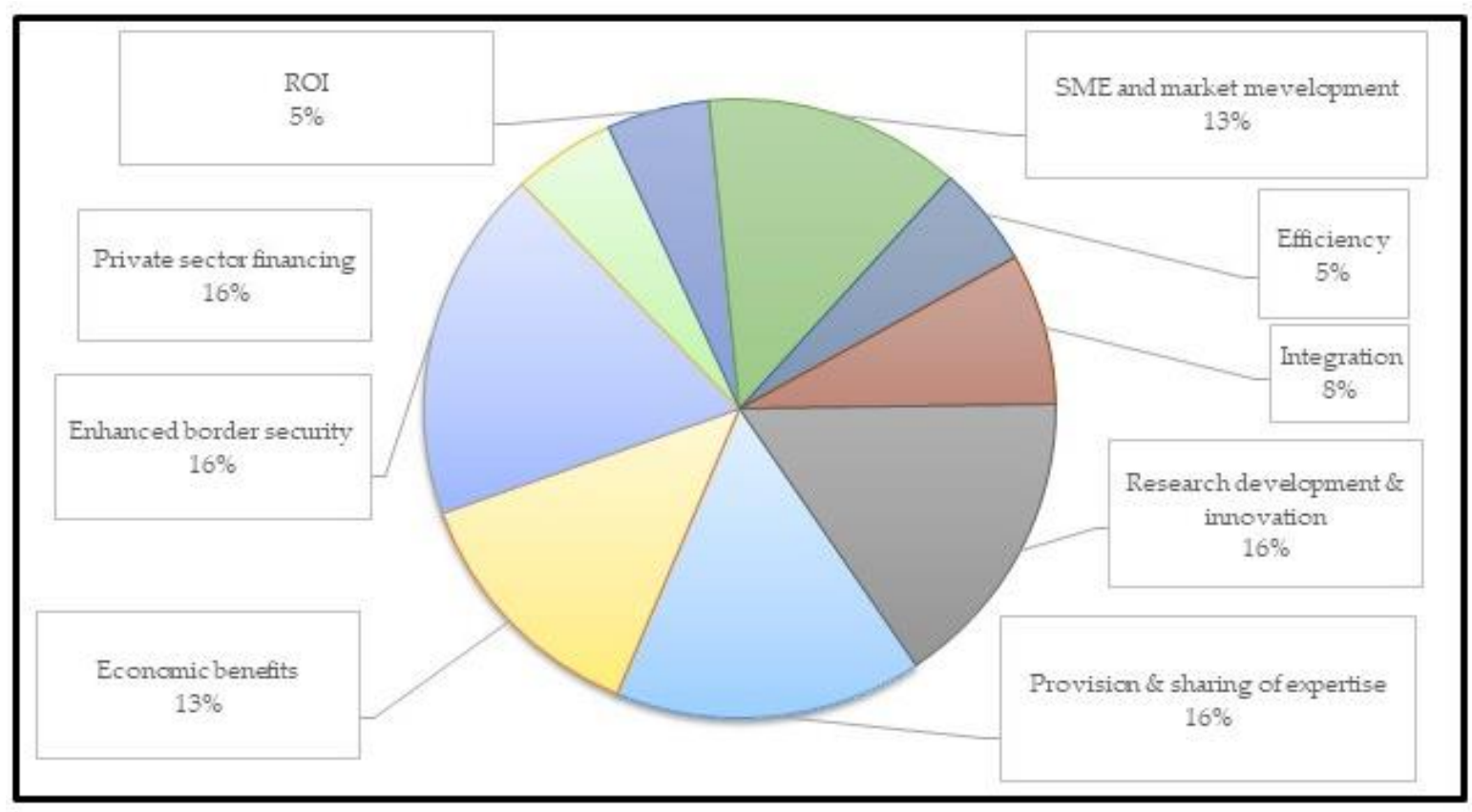

On the other hand, the study revealed several challenges that may be experienced in the envisaged partnerships. The sole participant in the field of satellite experts suggested that there would not be incentives for the private sector to engage in partnerships. The participants as presented in Figure 2 below further raised some concerns such as a lack of interest from the private space technology sector (34\%), partnerships would create other security challenges $(22 \%)$, there would be huge cost implications for the public sector $(22 \%)$. Moreover, the participants mentioned policy issues (11\%) and unequal partnership (11\%) as possible hindrances of implementing such a partnership. 
International Journal of Innovation, Creativity and Change. www.ijicc.net Volume 15, Issue 10, 2021

Figure 2: Potential challenges of PPPs

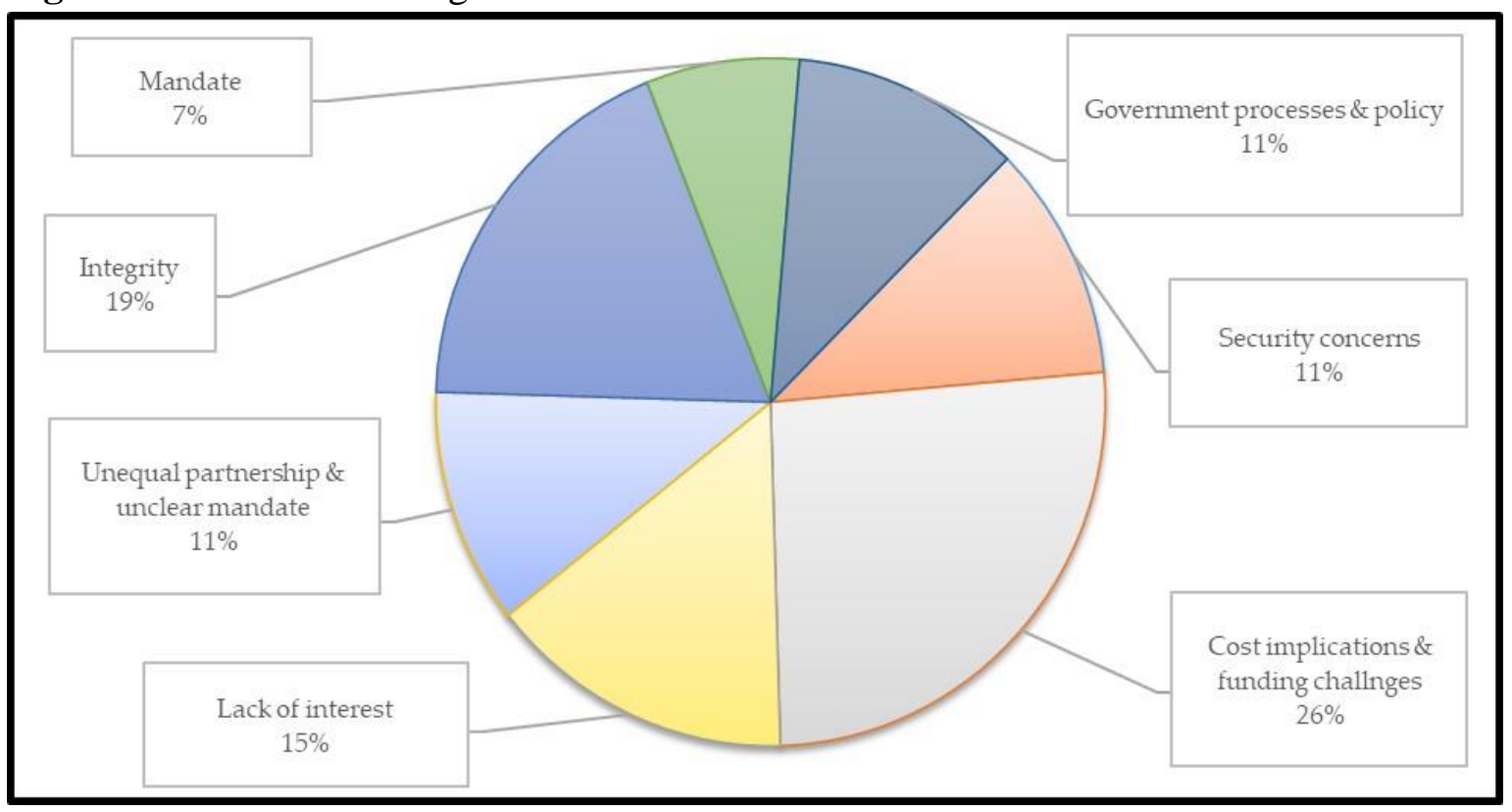

\section{Discussion}

It has been noted that space industry has mirrored other sectors of the economy by introducing PPPs in several space applications, such as remote sensing, global navigation, and international communication systems (Howard, 2008). Space technology-based PPPs have also been realised in strategic sectors such as the military to develop a military communication systems and high-speed internet to be acceded by various military units (Chutter, 2007; Betran \& Vidal, 2005; Iron \& Davidian, 2008; Pasztor, 2008). It has also been revealed that South Africa has the capability to develop and manufacture its own satellites and drones through effective partnerships with academic institutions and satellite and drone companies (Dahir, 2018; Scatteia et al., 2020; Parliamentary Monitoring Group, 2017; Wood \& Weigel, 2012; South Africa, 2020; Kesteloo, 2019; DefenceWeb, 2017).

Given the above, almost all the participants concurred that there should be partnerships between the private space technology industry and border security authorities in South Africa to enhance border security through the application of space technology. The participants mentioned several benefits that could be realised through effective partnerships. The benefits, mentioned by the participants, consisted of the sharing of expertise; the enhancement of border security; expedited technology innovation; and private sector financing. Moreover, the participants indicated that partnerships with the private sector were crucial because, with the regular advancements in technology, the government would not be able to work alone on technological issues, but would have to rely on the private sector, which was more capable and had business interests to control. The participants also mentioned that partnerships would result in financial, and costs benefits for the private space technology industry and the government. The participants also indicated that the envisaged partnerships would not be without challenges. 
The participants identified several challenges that could inhibit the effective implementation of the envisaged partnerships. They opined that the private sector would not be interested in engaging in such partnerships due to lengthy government processes, among others. They also raised participants cost implications which would discourage the public sector from engaging in such partnerships. The participants further indicated that the involvement of the private sector might compromise border security information and mission security. Corruption, a conflict of interest, and the risks of the envisioned partnerships were some of the inhibiting factors mentioned by the participants.

Figure 3 below depicts the envisaged partnership model. It depicts the relevant collaborators and the role of each party to the partnership. It further shows the primary and secondary uses of the technological solutions achieved through the envisaged partnerships. The role of the private space technology companies would mainly be on study and development, innovation, manufacturing, and financing. The private partner might also be required to carry substantial risk associated with the project and depending on the level of risk carried by the private partner, the private partner might claim patent rights associated with the development of products related to the project. Border security authorities would be the primary beneficiaries and will utilise the technology for border security activities. In addition, SAPS could use the same technologies intended for border security for its rural safety and policing activities.

Considering the issue of rural safety, the researcher holds a strong view that rural safety should not be separated from border security management. Therefore, collective efforts are necessary to address rural safety challenges, and not only farming-related safety and security concerns, but also all rural safety challenges faced by a variety of communities situated in remote areas near South Africa's borders. The government, on the other hand, would be responsible for creating an enabling environment; defining regulatory frameworks that would give effect to the partnership; and provide some level of funding towards the project. Other private, public and non-profit organisations could also be involved in study, and development and innovation. Border security authorities, other government departments, and private interest would be responsible for determining their space technological needs, the utilisation of the assets, and where necessary, the maintenance of the said assets depending on contractual agreements. The ability of the proposed technologies to be used for multiple purposes and by multiple government departments should also receive consideration. For example, UAVs and satellites could be used for other government programmes, such as environmental management and human settlement planning. UAVs, which have been dedicated for border security, could still be used for search and rescue missions by local authorities, such as provincial governments and municipalities. 
International Journal of Innovation, Creativity and Change. www.ijicc.net

Volume 15, Issue 10, 2021

\section{Figure 3: Proposed PPP model}

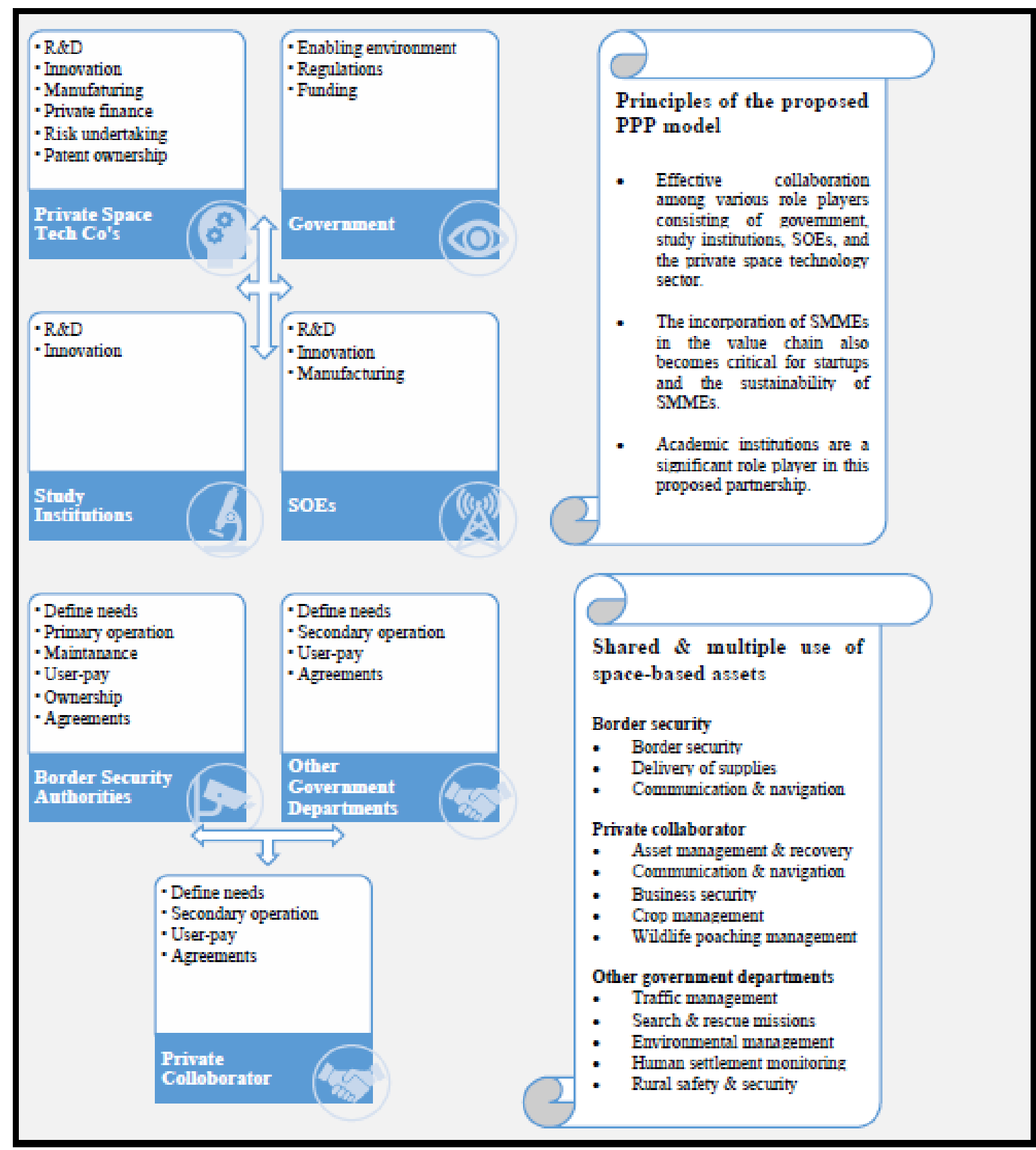

Source: Researcher's own illustration

The management of traffic near designated border posts could also be enhanced by utilising the same border security assets through collaborations between provincial and municipal traffic authorities and local border security authorities. The shared use of hi-tech assets, as identified in this study, by these authorities would enable them to monitor the flow of traffic into designated border posts effectively and efficiently. Traffic authorities would then be able to monitor the build-up of traffic and initiate reactive measures to remedy the situation. For 
example, the build-up of traffic and resultant congestion experienced during the 2020 festive season in border areas, such as Beitbridge and Lebombo, could have been identified on time and managed with the use of space technologies, such as satellites and UAVs. Another possible collaboration would be between vehicle tracking and recovery companies, as well as between border security authorities and commercial settings, such as farms and parks situated near the South African borders.

It has been highlighted that certain border areas, such as the South Africa-Zimbabwe and South Africa-Mozambique border areas, experience high incidences of the smuggling of stolen light motor and light delivery vehicles, which could run into millions of Rands in losses to the affected parties. Thus, assets management and recovery companies could benefit from the envisaged partnerships. National parks and private game reserves situated near South Africa's borders could also collaborate with border security authorities and the private space technology for the shared utilisation of border security resources. Wildlife poaching and smuggling is said to be rife in national parks situated near the South African border, such as the KNP, as discussed earlier in this study. Therefore, collaboration between the national parks and private nature reserves could curb wildlife poaching and smuggling. Moreover, as per the findings of this study, commercial farming entities near the South African borders continue to experience significant incidents of stock theft and property related crimes. As such, they could also benefit from the envisaged partnerships. It is anticipated that the envisaged partnerships will not be without challenges, as identified in this study.

Given all of the above, the multitude of role players in the border environment and the impact illegal cross-border activities have on their various interests clearly suggest the need for collaborative efforts to deal with cross-border criminal activities and to enhance the levels of border security in South Africa. The ability of the private space technology sector to design and develop solution-driven technologies and their willingness to collaborate with the government, as mentioned earlier in this study, provides valuable opportunities for effective partnerships between the private space technology sector, SOEs, SMEs, study organisations, all levels of government with an interest in border security and other activities at or near the borders of South Africa, and other private interests affected by cross-border criminal activities.

\section{Conclusion}

Evidence in this study suggested that there are opportunities for the South African border security authorities to collaborate with the private space technology sector for the provision of space technologies to be used for border security in the country. This type of partnership would look at aspects of research and development; innovation; skills transfer; and sharing of expertise. Moreover, this study found that the envisaged partnership could result in mutual benefits for both parties in that it could alleviate financial pressures on the contracting public sector institutions and other private entities through shared procurement and utilisation, whilst 
at the same time, resulting in economic benefits for the private space technology sector. The study also highlighted that partnerships would provide technological solution faster than traditional public procurement methods and would also allow for the development of specific and suitable space technologies based on the needs of the border security authorities. Moreover, partnerships will allow for the integration of a variety of technological systems, resulting in enhanced border security. As much as this study revealed a significant number of benefits of implementing partnerships for the development of space technologies for application in border security in South Africa, it also revealed potential challenges of engaging in such partnerships.

\section{Recommendations}

This study recommends effective partnerships consisting of border security authorities, other government departments, private business interests, and the private space technology sector. To attract the private space technology sector, the government should introduce incentives that encourage partnerships. The creation of longer-term technology development agreements might also encourage the participation of the private space technology sector. SMMEs have been recognised as critical role players in the development of a country's economy. They provide various goods and services and further create employment opportunities. Therefore, the government should introduce an incentive-based policy, which would make it mandatory for private parties in a partnership to utilise SMMEs during the various phases of the project. The policy should clearly state the minimum requirement for SMME participation in partnership projects. This would be beneficial to many satellites and UAS technologies SMMEs. 
International Journal of Innovation, Creativity and Change. www.ijicc.net

Volume 15, Issue 10, 2021

\section{REFERENCES}

Abrahamsen, R, \& Williams, MC. 2010. Security Beyond the State: Private Security in International Politics. Cambridge: Cambridge University Press.

Alfen, H.W. 2010. Public private partnership (PPP) as part of infrastructure management solutions - a structural approach of delimiting PPP from other Private Sector participation Models: Online. Available from: https://www.irbnet.de/daten/iconda/CIB_DC24063.pdf (accessed 11 October 2020).

Anderson, F. 2008. Radar sensor technology developments at CSIR DPSS in support of persistent, ubiquitous surveillance systems. Available online from: http://playpen.meraka.csir.co.za/ acdc/education/CSIR\%20conference\%202008/Proc eedings/CPA-0045.pdf (accessed 10 May 2019).

Available online from: https://www.pwc.fr/fr/assets/files/pdf/2020/3/en-france-pwcspace-practice-emergingspace-nations-paper.pdf(accessed 13 September 2020).

Avant, D.D. 2005. The market for force: the consequences of privatizing security. Cambridge: Cambridge University Press.

Betran, X \& Vidal, A. 2005. The implementation of a public-private partnership for Galileo: Comparison of Galileo and Skynet 5 with other Projects. ION GNSS 18th International Technical Meeting of the Satellite Division, 13-16 September 2005, Long Beach, CA. Available online from: https://citeseerx.ist.psu.edu/viewdoc/download?doi=10.1.1.456.4833\&rep=rep1\&type $=$ pdf (accessed 15 September 2019).

Braun, V. \& Clarke, V. 2006. Using thematic analysis in psychology. Qualitative research in Psychology, 3 (2): 77-101.

Busch, N.E. \& Given, A.D. 2012. Public-private partnerships in homeland security: opportunities and challenges, Homeland Security Affairs, 8(1): 1-24.

Byiers, B., Große-Puppendahl, S., Huyse, H., Rosengren, A. and Vaes. 2016. Principles for public-private partnerships - towards sustainability? Lessons from SAGCOT, healthcare in Lesotho, and Better Factories Cambodia. Available online from: https://ecdpm.org/wp-content/uploads/DP194-Principles-PPP-Byiers-

GrossePuppendahl-July-2016-ECDPM.pdf (accessed 13 July 2019).

Carr, M. 2016. Public-private partnerships in national cyber-security strategies, International
Affairs,
92(1):
43-62.
Available
from: https://www.chathamhouse.org/sites/default/files/publications/ia/INTA92103Carr.pdf (accessed 3 May 2020).

Carter, J. G. 2008. The structure and function of public-private partnerships for homeland security, Homeland Security Review, 2(3):235-251.

Chumba, C., Okoth, P., and Were, G. 2016. Effectiveness of border surveillance strategies in the management of transnational terrorism in Kenya and Somalia, International Journal of Political Science (IJPS), 2 (2): 39-53. Available online from: http://dx.doi.org/10.20431/2454-9452.0202004 (accessed 1 June 2019). 
International Journal of Innovation, Creativity and Change. www.ijicc.net Volume 15, Issue 10, 2021

Chutter, A. 2017. Airbus D\&S could lose out on satellite deal if UK seeks competition. Space Symposium. Available online from: https://www.defensenews.com/digitalshowdailies/spacesymposium/2017/04/18/airbus -d-s-could-lose-out-on-satellitedeal-ifuk-seeks-competition/ (accessed13 September 2020).

Clark, M., Cordes, J., \& Roberts, B. 2006. Public-private partnerships and homeland security, 99th Conference.

Colverson, S 2011. Sustainable development: is there a role for public-private partnerships? A summary of an IISD Preliminary Investigation. Available online at: http://www.iisd.org/markets/procurement (accessed 13 June 2019).

Corner Alliance. 2019. FAA Ramps up its public-private partnerships for drones. Available online from:https://www.corneralliance.com/blog/faa-ramps-up-its-publicprivatepartnerships-for-drones (accessed 13 January 2021).

Corti, L \& Gregory, A. 2011. AQDAS comparability: what about CAQDAS data exchange?, Forum of Social Qualitative Research, Volume 12, No. 1, Art. 35 - January 2011.

Council for Scientific and Industrial Research. 2019. Defence and security on land. Available from: $\quad$ http://defsec.csir.co.za/wpcontent/uploads/2012/09/TECHTHATTRANSFORMSLAND.pdf [accessed22 September 2019].

Cuttaree, V. 2008. Successes and Failures of PPP Projects. Washington, DC: Worldbank.

da Cruz, Nuno Ferreira, Simões, Pedro and Marques, Rui Cunha (2013) The hurdles of local governments with PPP contracts in the waste sector, Environment and Planning $C$ : Government and Policy, 31 (2). 292-307.

Dahir, A.L. 2018. Ethiopia is set to launch its first satellite into space with China's help. Quartz Africa, November 26. Available online from:https://qz.com/africa/1474369/china-tohelp-launch-ethiopias-first-satellite-in2019/ (accessed January 22, 2019).

De Vos, A.S., Strydom, H., Fouché, C.B. and Delport, C.S.L. 2005. Research at Grass Roots For the Social Science Professionals. 3rd Edition, Van Schaik, Pretoria.

DefenceWeb. 2017. DoD outlines 2017 defence priorities. Available online from: https://www.defenceweb.co.za/sa-defence/sa-defence-sa-defence/dod-outlines-2017defence-priorities/ (accessed 9 April 2020).

DeNardo, A.M. \& Levers, L.L. 2002. Using NVivo to analyze qualitative data. Education. Available online fromhttp://www.education.duq.edu/institutes/PDF/papers2002/DeNardo\&Levers.pdf [accessed, 25 March 2020].

Denner, F. 2018. The South African aerospace industry-an emerging priority sector, 9-10. Available online

from: https://www.researchgate.net/publication/298137972_The_South_African_aerospacei ndustry-Anemergingprioritysector (accessed 3 June 2020).

Dulaimi. M.F., Alhashemi, M., Ling, F.Y.Y, \& Kumaraswamy, M. 2010. The execution of the public-private-partnership projects in the UAE, Construction Management and Economics, 28: 393-402. 
International Journal of Innovation, Creativity and Change. www.ijicc.net Volume 15, Issue 10, 2021

Dunn-Cavelty, M. 2014. Breaking the Cyber-Security Dilemma: Aligning Security Needs and Removing Vulnerabilities, Science Engineering Ethics, 20: 701-715. Available online from: DOI 10.1007/s11948-014-9551-y (accessed 3 March 2020).

Farlam, P. 2005. Assessing public private partnerships in Africa. Nepad Policy Focus Series, South African Institute of International Affairs, Pretoria.

Foster, K. 2018. What Is A Socio-Technical System And Why Is It Important For Risk Management? Security Solutions, available online from: https://www.securitysolutionsmedia.com/2018/11/19/what-socio-technical-systemwhy-important-risk-management/ (accessed 5 March 2020).

Gadda, J.S., \& Patil, R.D. 2013. Quadcopter (UAVS) for border security with GUI system, International Journal of Research in Engineering and Technology, 2(12):620-624.

Given, L.M. 2008. The SAGE encyclopaedia of qualitative research methods. Thousand Oaks: SAGE.

Gratton, C., \& Jones, I. 2004. Research methods for sport studies. London: Routledge. Chicago Grimsey, D. and Lewis, M.K 2002. Evaluating the risks for public private partnerships for infrastructure projects, International Journal of Project management, 20(1): 107118.

Gwatiwa, T.T. 2016. Private military and security companies' policy in Africa: Regional policy stasis as Agency in international politics, Scientia Militaria, South African Journal of Military Studies, Vol 44 (2): 68-86. Available online from: https://doi.org/10.5787/442-1176 (accessed 12 May 2020).

Harvey, D. 2013. The political economy of public space. Available online from: https://davidharvey.org/media/public.pdf (accessed 13 May 2020).

Howard, D. 2008. Achieving a level playing field in Space-Related Public-Private Partnerships: Can Sovereign Immunity Upset the Balance, 73J. Air L. \& Com. 723. Available online from: https://scholar.smu.edu/jalc/vol73/iss4/2 (accessed 7 March 2020).

Ibeh, J. 2018. Why the South African Space Industry is Progressive. Space in Africa, available online from: https://africanews.space/why-the-south-african-space-industry-isprogressive/ (accessed 10 October 2020).

Iron, D.J., \& Davidian, K.2018. Applying the UK's PPP Lessons to NASA's Commercial Development Policy, American Institute of Aeronautics and Astronautics. Available online from: http://commercialspace.pbworks.com.pdf (accessed 6 April 2020).

Kawakubo, F. 2012. The transformation of border security practices from fixed borders to new modalities and privatisation: from the perspectives of critical border studies, Eurasia Border Review. Available online from: https://srch.slav.hokudai.ac.jp/publictn/eurasia_border_review/Vol81/Fuminori\%20Kawakubo. pdf [accessed 10 May 2019].

Kent, D. 1998. Secure partnerships, Private Finance Initiative Journal, 3(5): 15-18. 
International Journal of Innovation, Creativity and Change. www.ijicc.net

Volume 15, Issue 10, 2021

Kesteloo, H. 2019. South Africa looking at drones to secure the border. Available online from:https://dronedj.com/2019/03/12/south-africa-drones-secure-border/ (accessed 19 September 2019).

Kinsey, C. 2006. Corporate soldier and international security: the rise of private military companies. Routledge: London. Available online from: http://geopolitica.iiec.unam.mx/sites/default/files/201811/Christop\%20KinseyCorpora te\%20Soldiers\%20and\%20International\%20Security\%20\%20The\%20R ise $\% 20 \mathrm{of} \% 20 \mathrm{Private} \% 20$ Military $\% 20$ Companies $\% 20$ (Contemporary $\% 20$ Security $\% 2$ 0Studies)\%20(2006).pdf (accessed 12 June 2020).

Kumar, K. 1989. Conducting key informant interviews in developing countries. A.I.D. Program Design and Evaluation Methodology Report No. 13. http://www.slideshare.net/achintbt/usaid-tips-series (accessed 4 August 2020)

Levai, C. 2012. Theoretical and practical aspects of public-private partnership in the European Union, Acta Universitatis George Bacovia. Juridica, Bacău, 1(1): 15-25.

Liu, Y.; Liu, Z.; Shi, J.; Wu, G.; Chen, C. 2018. Optimization of base location and patrol routes for Unmanned Aerial Vehicles in border intelligence, surveillance and reconnaissance. Preprints. https://doi:10.20944/preprints201809. 0487.v1.

Martin, G. 2019. 22 companies not enough for border protection. DefenceWeb. Available online from: https://www.defenceweb.co.za/featured/22-companies-not-enough-forborder-protection/9 (accessed 30 May 2019).

McCharty, D.R. 2018. Privatizing political authority: cybersecurity, public-private partnerships, and the reproduction of liberal political order, Politics and Governance, 6(2): 5-12 DOI:10.17645/pag.v6i2.1335.

Motlagh, N.S., Bagaa, M. \& Taleb, T. 2017. UAV-based IoT platform: a crowd surveillance use case, IEEE Communications Magazine. Available from: https://DOI:10.1109/mcom.2017.1600587c [accessed 18 May 2019].

Nederhand, J. Klijn, E.H. 2019. Activating citizens in Dutch care reforms: framing new coproduction roles and competences for citizens and professionals, Administration \& Society, 51 (8):1200-1226.

Osborne, S.P. 2000. Public-private partnerships: theory and practice in international perspective. London: Routledge

Parliamentary Monitoring Group. 2017. Defence and Military Veterans. Border Control: briefing by Chief of Joint Operations, South African National Defence Force (SANDF), 16 February 2010, Chairperson: Mr M Booi (ANC). Available online from: https://pmg.org.za/committee-meeting/11206/ (accessed 1 July 2020).

Parliamentary Monitoring Group. 2017. Space: Department of Science and Technology briefing. Science and Technology. Available online from: https://pmg.org.za/committee-meeting/24446/(accessed 12 September 2019).

Scatteia, L., Frayling, A., \& Atie, T. 2020. The role of emerging space nations in supporting sustainable development and economic growth. Price Water Coopers 
International Journal of Innovation, Creativity and Change. www.ijicc.net Volume 15, Issue 10, 2021

South Africa. 2020. South African Government, Justice, Crime Prevention \& Security Cluster. Available online from: https://www.gov.za/aboutgovernment/justice-crimeprevention-security-cluster-1 (accessed 2 May 2020).

South African Council for Space Affairs. 2020. Space Science and Space Technology. Available online from: http://www.sacsa.gov.za/space-science-and-space-technology/ (accessed 2 May 2020).

Spaceteq. 2020. About. Available online from: https://www.spaceteq.co.za/ (accessed 1 August 2020).

Spackman, M. 2002. Public-private partnerships: lessons from the British approach, Economic Systems, Elsevier, 26(3), 283-301.

The Canadian Council of Public-Private Partnerships. 2019. Definitions and models. Available online from: https://www.pppcouncil.ca/web/KnowledgeCentre/web/P3_KnowledgeCentre/P3Kno wledgeCentre.aspx (accessed 15 July 2019).

Webb, R., and Pulle, B. 2002, Public-private partnerships: an introduction, Research Paper No. 1 2002-03, Economics and Industrial Relations Group, Parliament of Australia, September 24.

Welman, J., Kruger, S.J., \& Mitchel, B. 2005. Research methodology. 3rd Edn. Cape Town:

Wood, D \& Weigel, A. 2012. Charting the evolution of satellite programs in developing countries, The Space Technology Ladder, 28(1): 15-24. Available online from: https://doi.org/10.1016/j.spacepol.2011.11.001 (accessed 3 May 2020). 